\title{
How Codes of Ethics Deal with Fear in the Workplace
}

\author{
Pierluigi Santosuosso ${ }^{1}$ \\ ${ }^{1}$ School of Economics, Sapienza University of Rome, Rome, Italy \\ Correspondence: Pierluigi Santosuosso, School of Economics, Sapienza University of Rome, Rome, Italy. E-mail: \\ pierluigi.santosuosso@uniroma1.it
}

Received: August 24, 2016

Accepted: September 8, 2016

Online Published: September 23, 2016

doi:10.5539/ibr.v9n11p29

URL: http://dx.doi.org/10.5539/ibr.v9n11p29

\begin{abstract}
The relationship between decision-making and emotions has been increasingly explored in the past thirty years by physicians, psychologists and economists. Because of the impact that emotions have on human behaviour, ethical implications need to be examined if we consider that managers could use emotions to motivate employees. This paper analyses the content of the code of ethics of 278 companies listed on the Italian stock exchange in order to verify how the codes take into account the emotion of fear experienced by employees in the workplace. Research findings revealed that companies have failed to consider the word "fear" and most of the other terms expressing similar emotions. On the other hand, their codes of ethics focused on ethical standards that should be respected, such as the dignity of each single individual and on unethical actions that must be avoided, such as acts of physical or psychological violence.
\end{abstract}

Keywords: code of ethics, fear, emotions, Italian listed companies

\section{Introduction}

In the last decades, a large number of studies have analyzed the prominent role that emotions have in influencing judgments and choices of individuals (e.g. Loewenstein \& Lerner, 2003; Lerner, Li, Valdesolo, \& Kassam, 2015). Examples of emotions that have been most frequently analysed by physicians, psychologists and economists are anger, fear, sadness, joy and disgust (e.g. Angie, Connelly, Waples \& Kligyte, 2011). These emotions have the potential to affect human reactions, cognition and behaviour. Research literature on emotions and decision-making offers further valuable discussions about various theoretical and practical issues. For example, some studies have argued that emotional displays of other persons are considered as information available to guide our decisions (Campellone \& Kring, 2013). A growing body of literature has also investigated how emotions affect ethical decision-making (Etzioni, 1988; Bos \&Willmot, 2001; Gaudine \& Torne, 2001; Connelly, Helton-Fauth, \& Mumford, 2004; Lurie, 2004; Wenstøp, 2005; Krishnakumar \& Rymph, 2011; Fetterman \& Robinson, 2013; Kligyte, Connelly, Thiel, \& Devenport 2013; Lee \& Gino, 2015), testifying the importance that emotions play in moral reasoning in the light of Western ethical theories and also Confucian ethics (Zhu, 2015).

We are specifically interested in examining the emotion of fear in the workplace. Fear is commonly considered a basic emotion. Basic emotions, such as fear, anger, sadness, disgust and joy, are not created by human mind but are discovered when various sensory stimuli automatically trigger physical reactions (Izard, 2007; Barnett, 2006). From this point of view, fear is inherent in humans as a defence mechanism that the evolutionary process has selected in order to face situations of impending danger. Although the notion of basic emotion is not without uncertainty (Ortony \& Turner, 1990), examples of distinctive features of basic emotions are their neurobiological roots, universal antecedent events and a motor and facial expressions response (Ekman, 1999). Aware of the existence of psychological processes that are beyond a merely natural-kind view of emotions (Barnett, 2006), fear also has the ability to influence the cognitive process and the behaviour of individuals (e.g. Izard, 2007; Lerner, Li, Valdesolo, \& Kassam, 2015).

The analysis of fear in a business context also raises issues that have various ethical implications. Just consider that fear could be used unintentionally or deliberately by managers to direct and/or to correct the behaviour of employees in order to achieve business goals, causing physical pain and psychological distress for a short or long period. In view of the impact that fear has on human behaviour, the purpose of this paper is to examine how the code of ethics adopted by many firms around the world deals with this issue by searching for the word "fear" in the content of the codes of ethics and for a number of other words that approximately describe this emotion. 
The sample examined in this study contains 278 codes of ethics of companies listed on the Italian stock exchange (Borsa Italiana). Although philosophical thinking on this topic (e.g. Solomon, 2008) would need an in-depth analysis, this study is carried out regardless of an evaluation about the morality of actions that could frighten employees. More specifically, we assumed that the morality of the use of fear by managers to drive employees with a prospect of achieving business goals can be solved in different ways depending on the moral principles of decision-makers (Goodchild, 1986; Reynolds, 2006). For example, if a consequentialist moral doctrine such as utilitarianism affects the choices of managers, the action that frightens some employees and generates pain and unhappiness could be evaluated ethical if it produces an increasing total amount of pleasure and happiness for all the other employees and firm's stakeholders. By contrast, when decision-making is based on a deontological approach, such as Kant's ethics, the action that frightens some employees could be considered inherently unethical since it violates the principle of morality known as Categorical Imperative (for a review of moral doctrines, Shaw, 2005; Velasquez, 2006; Weiss, 2006).

The remainder of this study is organized as follows: the second section provides a review of the related literature, the third section presents the sample of codes of ethics and the survey methodology; the fourth section reports on the results; the last section gives concluding remarks.

\section{Theoretical Background}

To our knowledge, there is no explicit reference to the emotion of fear in the numerous analyses on the content of the codes of ethics adopted by many firms around the world (Cressey \& Moore, 1983; Kaptein, 2004; Carasco \& Singh, 2003; Singh, Svensson, Wood, \& Callaghan, 2011), just as no mention of the morality of the use of fear by management can be found in the research literature in the field of business ethics.

Although researchers have not specifically addressed the aforementioned issues, several references have been made to the so-called fear of retaliation when employees fear repercussions (in the form of exclusion from decisions, a cold shoulder, verbal abuse, demotion, etc.) as a result of reported misconduct. Retaliation in a business context has been examined in surveys in American workplaces by analyzing the opinions of employees (Callahan \& Collins, 1992; Ethics Resource Center, 2014). Fear of retaliation is considered a factor that stops questioning (Flanagan \& Clarke, 2007), an obstacle for the creation of an ethical corporate culture (Webley \& Werner, 2008) that contributes to the reduced effectiveness of the code of ethics and in general of corporate ethics and compliance programs in both the private-sector (Barnett, 2006; Trevino, Weaver, Gibson, \& Toffler, 1999; Guerrette, 1988; KPMG, 2009) and in local government (Van Zolingen \& Honders, 2010). To a lesser extent, fear is also used as fear of discipline. Some studies suggested that the fear of disciplinary action resulting from employees' misconduct is a factor that contributes to compliance with the code of ethics (Schwartz, 2001; Laufer \& Robertson, 1997).

On the contrary, an essential support for economic research was provided by a large volume of published studies describing the biological and the psychological effects that fear has on human reactions and on decision-making.

The analysis of biological effects provides the first important contribution to the research conducted on fear. Neural circuits involved in fear processing have been explored extensively by neuroscientists based on increasingly technological advanced methods (Dejean et al., 2015; Dunsmoor \& Paz, 2015). Although the intricate functioning of the human brain still remains to be discovered, recent studies have suggested that fear is processed by distinct neural substrates (for a review, Herry \& Johansen, 2014). Various sensorial stimuli, visual, auditory, olfactory and tactile stimuli, are transmitted to the thalamus (a dual lobed structure situated between the cerebral cortex and the midbrain) and from thalamic nuclei to the amygdala (an almond-shaped structure located in the brain's medial temporal lobe) and to the cerebral cortex. The cerebral cortex also sends information to the amygdala updating fear-related information. The thalamo-amygdala subcortical path-way allows the central nervous system to react rapidly to sensory stimuli while the thalamo-cortex-amygdala path-way gives a more complete assessment of information detected by the sensory system. The amygdala, mediated by the hypothalamus located below the thalamus in the middle of the base of the brain, triggers the autonomic nervous system in a reflexive and involuntary manner, generating an increase in sweating, heart rate, blood pressure, pupil dilation, freezing and facial expression. The physical and psychological distress due to fear responses tend to subside when dangerous situations are no longer looming, unless anxiety disorders take place if fear responses are triggered by innocuous stimuli (for a review, Calder, Lawrence, \& Young, 2001; Kim \& Jung, 2006; Ledoux \& Phelps, 2008; Tsvetkov, Krasnoshchekova, Vesselkin, \& Kharazova, 2015).

A second considerable amount of literature has been published on the effects that fear has on a human being's cognitive process which includes perceiving, recognizing, conceiving and reasoning. According to a valence-based approach, where emotions have a bipolar dimension (Angie, Connelly, Waples, \& Kligyte, 2011), 
empirical studies have suggested that negative (e.g. sadness) or positive (e.g. happiness) affects can induce decision-makers to process information differently. Although several studies were not directly focused on fear, research findings suggested that positive affects tend to be connected with heuristic processing, whereas negative effects are associated with systematic processing of information (for a review, Bless et al., 1996; Tiedens \& Linton, 2001; Lerner, Li, Valdesolo, \& Kassam, 2015). More specifically, fear has been associated with pessimistic likelihood judgments (Maner \& Gerend, 2007) that induce people to make risk-averse choices (Lerner \& Keltner, 2001). Risk-averse behaviour was reported in laboratory experiments in the case of stock investment decisions (Lee \& Andrade, 2011, 2015), facing terror risk (Fischhoff, Gonzalez, Lerner, \& Small, 2005), testing habitual use of emotion regulation strategies (Panno, Lauriola, \& Figner, 2013), deciding under time pressure (Hu, Wang, Pang, Xu, \& Guo, 2015) and when uncertainty depends on a randomizing device (Kugler, Connolly, \& Ordónez, 2012). Some circumstances affecting the cognitive process have also been explored in several studies. For example, it has been suggested that individuals are less affected by anxiety when they are informed about its source (Yip \& Côté, 2012). Fear can induce employees to speak openly when they perceive their supervisors prepared to listen to different points of view (Lebel, 2016), fear also leads to focussing excessively on catastrophic events (Chanel \& Chichilnisky, 2009) and fearful people are less risk-averse than angry people when uncertainty depends on the behaviour of other persons (Kugler, Connolly, \& Ordónez, 2012) or if financial traders believe that stock values are generated by a computer (Lee \& Andrade, 2011).

\section{Sample and Methodology}

This study examined the codes of ethics of 278 listed companies on the Italian stock exchange including the AIM Italia market devoted to small and medium firms (Table 1). Each code of ethics was downloaded from the companies' websites at the date of our analysis (July, 2016). The codes of 130 listed companies were not included in the sample because ethical codes have not been adopted by these companies or were not available on their website. We also excluded from the sample the codes of ethics that were not available in Italian in order to have a more homogeneous sample since the analysis of the content of the codes was carried out by searching exact keywords in Italian. Furthermore, a limited number of codes was excluded (n. 3 codes) since it was not possible to activate the "search" function for a PDF document. On the basis of these selection criteria, the companies included in our sample operate in various industries and account for $68 \%$ of Italian listed companies.

The analysis of the codes was carried out by searching for the word "fear" and for a number of words that approximately have a similar meaning, namely, "anxiety", "terror", "panic", "distress", "dismay", "oppression", "humiliation", "discomfort", "offense" and "pain" (group 1). Although the above mentioned words indicate emotions that are not identical to each other, these terms express a situation of physical or psychological harm.

Second, some words with a positive value were also examined. In this group, we considered the terms "listening", "dialogue", "dignity", "serenity" and "sensibility" (group 2). Ceteris paribus, the presence of these terms presumably reveals the attention that companies should have for the emotions and feelings of each single individual. The use of the terms included in this group of words that have a double meaning in the economic context has been avoided as much as possible (e.g. market abuse versus sexual abuse). In a few cases, the research has required a detailed and separate analysis of the content of the codes in order to identify the appropriate meaning of these terms. In particular, the words "dialogue" and "listening" were recorded only if they refer to employees with the exclusion of the other stakeholders.

Lastly, the analysis was conducted by searching for the words that denote the types of action that can frighten employees. These terms are "harassment", "intimidation", "reprisals", "humiliate", "threat", "violence", "coercion", "blackmail" and "retaliation" (group 3).

We counted the number of the pth word (WD) that was found in each code of ethics. On the basis of these data, several variables were provided for each of the three above-mentioned groups of words. More specifically, in the present analysis, NW denotes the total number of the pth word that was found in all the codes of ethics included in our sample. $\mathrm{NC}$ is the total number of codes containing the pth word and $\mathrm{NC} \%$ shows the ratio of $\mathrm{NC}$ to the total number of ethical codes included in the sample. MEDIANW and MEANW are respectively the median and the mean of the frequency distribution of the pth word WD that was found in each code of ethics. Similarly, the $10^{\text {th }}$ and the $90^{\text {th }}$ percentile were also computed. In addition to the above-mentioned variables, we focused on a measure of statistical dispersion in order to analyse the inequality of the distribution of WD. In particular, we computed the Gini coefficient of WD (GINIW). The Gini coefficient measures the statistical dispersion with values between 0 and 1 . A Gini coefficient of 1 expresses maximal inequality among values whereas the coefficient of 0 corresponds to perfect equality. 
Table 1. Sample of 278 companies listed on the Italian stock exchange

\begin{tabular}{|c|c|c|c|c|c|c|}
\hline $\mathrm{A} 2 \mathrm{a}$ & Bca P. Em. R & Cofide Spa & Fidia & Juventus Fc & Piaggio & Siti - B\&T \\
\hline Acea & Bca Pop Etr. L. & Conafi Prestito' & Fiera Milano & K.R.Energy & Pierrel & Snai \\
\hline Acotel & Bca Pop Milano & Credem & Fila & L'oreal & Pininfarina Spa & Snam \\
\hline Acsm-Agam & Bca P. Sondrio & C. Valtellinese & Fincantieri & La Doria & Piquadro & Softec \\
\hline Aedes & Bco Desio Br. & Csp Int. & Finecobank & Landi Renzo & Piteco & Sogefi \\
\hline Aeffe & Bco Sardegna & D'amico & Fintel Energia & Leonardo - Fin. & Plt Energia & Sol \\
\hline Aeroporto di Bo & $\mathrm{Be}$ & Dada & First Capital & Leone Film Gr. & Poligraf. S. F & Stefanel \\
\hline Air Liquide & Beghelli & Daimler & Fnm & Linde & Poligrafici Edit & Stefanel \\
\hline Airbus Group & Beiersdorf & Damiani & Fullsix & Lucisano M. Gr & Poligrafici Pr. & Tamburi \\
\hline Alcatel-Lucent & Best Union C. & Danieli \& C & Gabetti & Luxottica Gr. & Poste Italiane & Tas \\
\hline Alerion & Bialetti Indus. & Danone & Gala & Lventure Gr. & Prelios & Tbs Group \\
\hline Allianz & Biancamano & Datalogic & Gas Plus & $\mathrm{M} \& \mathrm{C}$ & Premuda & Technogym \\
\hline Ambienthesis & Biesse & De'longhi & Gefran & Mailup & Prima Industrie & Tecnoinvest. \\
\hline Ambromob. & Bio On & Dea Capital & Generali Ass & Maire Tecn. & Pr. Sui Motori & Telecom Italia \\
\hline Amplifon & Bmw & Deutsche Bank & Geox & Marr & Prysmian & Tenaris \\
\hline Ansaldo Sts & Bnp Paribas & Diasorin & Giorgio Fedon & M. Zanetti Bev. & Rai Way & Terna \\
\hline Ascopiave & Boero Bartol. & Digital Bros & Go Internet & Mc-Link & Ratti & Ternienergia \\
\hline Assiteca & Bomi Italia & E.On & Gr Green Power & Mediacontech & Rcs Mediagroup & Tesmec \\
\hline Astaldi & Bon. Ferraresi & Ecosuntek & Gr Waste Italia & Mediaset S.P.A & Recordati Ord & Tiscali \\
\hline Astm & Brembo & Edison & Henkel Vz & Mediobanca & Renault & Tod's \\
\hline Atlantia & B. Cucinelli & Eems & Hera & Meridie & Reno De Medici & Toscana Aerop. \\
\hline Autogrill Spa & Buzzi Unicem & Ei Towers & I.M.A & Methorios Cap. & Reply & Trevi Fin Ind \\
\hline Autostrade M. & Cad It & El.En & Igd & Mid Ind. Cap. & Retelit & Triboo Media \\
\hline Azimut & Caleffi & Elica & Immsi & Mittel & Risanamento & Txt E-Solutions \\
\hline B\&C Speakers & Caltagirone & Emak & Imvest & Moleskine & Rosss & Ubi Banca \\
\hline Banca Generali & Caltagirone Edit & Enav & Industria e Inn. & Moncler & Rwe & Unicredit \\
\hline Banca Ifis & Campari & Enel & Iniz. Bresciane & Mondadori Ed. & Sabaf & Unipol \\
\hline Banca Interm. & Carraro & Enervit & Interpump Gr. & Mondo Tv & Saes Getters & Unipolsai \\
\hline Banca Mediol. & Cattolica Ass & Engie & Intesa Sanpaolo & Monrif & Safilo Group & Vetrya \\
\hline Banca Sistema & Cdr Advance C. & Eni & Inv. e Sviluppo & Mp7 Italia & Saipem & Vianini \\
\hline Banco Popolare & Cembre & Erg & Inwit & Mutuionline & Salini Impregilo & Visibilia Editore \\
\hline Banco Santand. & Cementir Hldg & Esprinet & Irce & Net Insurance & S.Ferragamo & Vita Societa Ed. \\
\hline Banzai & Cent. Latte To & Eukedos & Iren & Nice & Sanofi & Vittoria Ass \\
\hline Basicnet & Cerved Inf. & Eurotech & Isagro & Noemalife & Saras & Volkswagen \\
\hline Bastogi Spa & Chl & Evonik Ind. & Isagro Az. Svil. & Nova Re & Save & Yoox Net-A-P. \\
\hline Bayer & Cia & Exor & Italcementi & Olidata & Servizi Italia & Zephyro \\
\hline Bca Carige & Ciccolella & Exprivia & Italia Indep. & Openjobmetis & Sesa & Zignago Vetro \\
\hline Bca Finnat & Cir & Falck Renew. & Italiaonline & Ovs & Sias & Zucchi Spa \\
\hline Bca Mps & Class Editori & Ferrari & Italmobiliare & Parmalat & Siemens & \\
\hline Bca P. Spoleto & Cnh Industrial & Fiat Chrysler & Ivs Group & Philips & Sintesi & \\
\hline
\end{tabular}

Note. The sample is composed of the codes of ethics of 278 Italian listed companies available on the company website (July, 2016). Codes are included in the sample if a PDF Document in Italian was available.

\section{Results}

The results of the analysis of the codes of ethics are presented in Table 2. In particular, Panel A of Table 2 shows the variables related to the word "fear" and to the words that have a similar meaning, Panel B presents the findings relating to the words with a positive value and Panel $\mathrm{C}$ contains the main results for the words that denote the types of action that can frighten employees. The analysis revealed two main findings.

First, companies have failed to consider the word "fear" and most of the terms expressing similar emotions, whereas the words that express positive ethical values and actions that should be avoided were used more frequently. In more detail, the word "fear" was detected only twice in a single code of ethics in relation to sexual, racial and religious discriminations (see the L'Oréal company's code) and a limited number of observations relating to the words of the first group was found. Accordingly, the Gini coefficient for the entire group 1 of words assumed a value close to 1 (GINIW $=0.7981$ ), suggesting the presence of a high degree of inequality about the use of these words. When the analysis focused on the words of group 3 that refer to the types of action that can frighten employees, a greater number of observations and a higher equality (GINIW $=0,6249$ ) were detected. An example of this type of expression commonly used in the codes is "the Company protects workers from acts of psychological violence and is opposed to any attitude or action that harms a human being" (see the Astaldi company's code). Furthermore, the frequency of the words that express a positive value included in group 2 was higher than the frequency found in the other two groups and the inequality among observations, measured by the Gini coefficient, was much lower (GINIW = 0,4555). 
Table 2.Content Analysis Results

\begin{tabular}{|c|c|c|c|c|c|c|c|c|}
\hline Word (WD) & NW & $\mathrm{NC}$ & $\mathrm{NC} \%$ & MEDIANW & MEANW & 10th perc. & 90th perc. & GINIW \\
\hline \multicolumn{9}{|c|}{ Panel A - Group 1} \\
\hline Fear & 2 & 1 & $0.36 \%$ & 2 & 2.000 & 2 & 2 & 0.9964 \\
\hline Anxiety & 0 & 0 & $0.00 \%$ & 0 & 0.000 & 0 & 0 & \\
\hline Terror & 1 & 1 & $0.36 \%$ & 1 & 1.000 & 1 & 1 & 0.9964 \\
\hline Panic & 0 & 0 & $0.00 \%$ & 0 & 0.000 & 0 & 0 & \\
\hline Distress & 0 & 0 & $0.00 \%$ & 0 & 0.000 & 0 & 0 & \\
\hline Dismay & 0 & 0 & $0.00 \%$ & 0 & 0.000 & 0 & 0 & \\
\hline Oppression & 9 & 8 & $2.88 \%$ & 1 & 1.125 & 1 & 1.3 & 0.9740 \\
\hline Humiliation & 4 & 4 & $1.44 \%$ & 1 & 1.000 & 1 & 1 & 0.9856 \\
\hline Discomfort & 42 & 37 & $13.31 \%$ & 1 & 1.135 & 1 & 1 & 0.8818 \\
\hline Offense & 49 & 39 & $14.03 \%$ & 1 & 1.256 & 1 & 2 & 0.8844 \\
\hline Pain & 1 & 1 & $0.36 \%$ & 1 & 1.000 & 1 & 1 & 0.9964 \\
\hline Total & 109 & 75 & $26.98 \%$ & 1 & 1.453 & 1 & 3 & 0.7981 \\
\hline \multicolumn{9}{|c|}{ Panel B - Group 2} \\
\hline Listening & 45 & 28 & $10.07 \%$ & 1 & 1.607 & 1 & 3.3 & 0.9286 \\
\hline Dialogue & 30 & 17 & $6.12 \%$ & 1 & 1.765 & 1 & 3.4 & 0.9585 \\
\hline Dignity & 552 & 222 & $79.86 \%$ & 2 & 2.487 & 1 & 5 & 0.4817 \\
\hline Serenity & 28 & 26 & $9.35 \%$ & 1 & 1.077 & 1 & 1 & 0.9126 \\
\hline Sensibility & 109 & 77 & $27.70 \%$ & 1 & 1.416 & 1 & 2 & 0.7821 \\
\hline Total & 764 & 233 & $83.81 \%$ & 3 & 3.278 & 1 & 6 & 0.4555 \\
\hline \multicolumn{9}{|c|}{ Panel C - Group 3} \\
\hline Harassment & 78 & 54 & $19.42 \%$ & 1 & 1.444 & 1 & 2 & 0.8549 \\
\hline Intimidation & 30 & 27 & $9.71 \%$ & 1 & 1.111 & 1 & 1.4 & 0.9115 \\
\hline Reprisals & 3 & 1 & $0.36 \%$ & 3 & 3.000 & 3 & 3 & 0.9964 \\
\hline Humiliate & 4 & 4 & $1.44 \%$ & 1 & 1.000 & 1 & 1 & 0.9856 \\
\hline Threat & 60 & 37 & $13.31 \%$ & 1 & 1.622 & 1 & 3 & 0.9095 \\
\hline Violence & 144 & 91 & $32.73 \%$ & 1 & 1.582 & 1 & 3 & 0.7736 \\
\hline Coercion & 10 & 10 & $3.60 \%$ & 1 & 1.000 & 1 & 1 & 0.9640 \\
\hline Blackmail & 3 & 3 & $1.08 \%$ & 1 & 1.000 & 1 & 1 & 0.9892 \\
\hline Retaliation & 143 & 117 & $42.09 \%$ & 1 & 1.222 & 1 & 2 & 0.6451 \\
\hline Total & 475 & 177 & $63.67 \%$ & 2 & 2.683 & 1 & 5 & 0.6249 \\
\hline Overall total & 1347 & 244 & $87.77 \%$ & 4 & 5.524 & 1 & 10.7 & 0.4588 \\
\hline
\end{tabular}

Note. Group 1 contains the word "fear" and similar words; Group 2 includes words with a positive value; Group 3 presents words expressing types of action that can frighten employees.

Second, companies tend to use unequally the terms examined in this study as revealed, with some exceptions, by the low values of NC\% and by the high values of the Gini Coefficient. The most frequently used word was "dignity" in group $2(\mathrm{NW}=552)$, which was found in almost $80 \%$ of the codes of ethics $(\mathrm{NC} \%=79,86 \%)$ with a Gini Coefficient of 0,48. This term was often used by companies in order to underline their commitment in "protecting the physical and moral integrity of employees ensuring safe and healthy work environments and working conditions that respect the individual dignity" (see the Hera company's code). The use of the word "violence" $(\mathrm{NW}=144)$, "retaliation" $(\mathrm{NW}=143)$ and "sensibility" $(\mathrm{NW}=109)$ showed a lower percentage of $\mathrm{NC} \%(\mathrm{NC} \%=32,73 \%$ for "violence", $\mathrm{NC} \%=42,09 \%$ for "retaliation" and $\mathrm{NC} \%=27,7 \%$ for "sensibility") and a higher GINIW that varies between 0,64 and 0,78. The other words analysed in this study were used by companies in a much lower percentage not exceeding $20 \%$ (in particular, for the word "harassment") with higher values of the Gini Coefficient (around or above 0,9). About $12 \%$ of the codes included in the sample did not show any of the words included in the three groups of words.

In sum, research findings revealed the exclusion in formal terms of fear from the ethical standards set out in the code of ethics as shown by the non-use of the word. On the other hand, codes of ethics mainly focused on ethical standards that should be respected and on unethical actions that must be avoided.

\section{Concluding Remarks}

A considerable amount of literature has been increasingly published in the last decades on emotions by physicians, psychologists and economists. Like other basic emotions, fear affects human reactions altering individuals' choices and behaviours. On the basis of these phenomena, fear could therefore be used by managers to motivate employees to achieve business goals with a number of relevant ethical questions. This paper has explored the content of the code of ethics of 278 companies listed on the Italian Stock Exchange in order to verify whether fear is formally taken into account by management when ethical values are set out in the codes.

This study revealed two main findings. First, our analysis documented the non-use of the word "fear" in the 
ethical standards set out in the code of ethics and a limited number of similar words were also reported. On the other hand, the codes of ethics took into account, with numerous observations, the ethical standards that deserve to be held in respect and unethical actions that should be avoided. However, it remains unclear if the codes really have framed and defined the issue of fear in a business context. Second, our examination suggested that companies tend to use unequally the words analysed in this study as revealed, with some exceptions, by the high values of the Gini coefficient.

The results of the content analysis have at least two implications. First, although further research should be done to investigate this issue, the research findings of the present paper provide insight into the current codes of ethics practices related to the use of the word "fear" and to the actions that can frighten employees. A second important implication is that ethical dilemmas involving the emotion of fear should be taken into account by management when a code of ethics is adopted. The value of dignity, sensitivity and/or the actions expressed by the words "violence" and "retaliation" do not focus precisely on the emotion of fear that employees could experience in a business context.

\section{References}

Angie, A. D., Connelly, S., Waples, E. P., \& Kligyte, V. (2011). The influence of discrete emotions on judgement and decision-making: A meta-analytic review. Cognition and Emotion, 25(8), 1393-1422. http://dx.doi.org/10.1080/02699931.2010.550751

Barrett, L. F. (2006). Are emotions natural kinds? Perspectives on psychological science, 1(1), 28-58. http://dx.doi.org/10.1111/j.1745-6916.2006.00003.x

Bless, H., Clore, G. L., Schwarz, N., Golisano, V., Rabe, C., \& Wölk, M. (1996). Mood and the use of scripts: Does a happy mood really lead to mindlessness? Journal of Personality and Social Psychology, 71(4), 665-679. http://dx.doi.org/10.1037/0022-3514.71.4.665

Bos, R. T., \& Willmott, H. (2001). Towards a post-dualistic business ethics: Interweaving reason and emotion in working life. Journal of Management Studies, 38(6), 769-793. http://dx.doi.org/10.1111/1467-6486.00258

Calder, A. J., Lawrence, A. D., \& Young, A. W. (2001). Neuropsychology of fear and loathing. Nature Reviews Neuroscience, 2(5), 352-363. http://dx.doi.org/10.1038/35072584

Callahan, E. S., \& Collins, J. W. (1992). Employee attitudes toward whistleblowing: Management and public policy implications. Journal of Business Ethics, 11(12), 939-948. http://dx.doi.org/10.1007/BF00871960

Campellone, T. R., \& Kring, A. M. (2013). Who do you trust? The impact of facial emotion and behaviour on decision making. Cognition \& Emotion, 27(4), 603-620. http://dx.doi.org/10.1080/02699931.2012.726608

Carasco, E. F., \& Singh, J. B. (2003).The content and focus of the codes of ethics of the world's largest transnational corporations. Business and Society Review, 108(1), 71-94. http://dx.doi.org/10.1111/1467-8594.00007

Chanel, O., \& Chichilnisky, G. (2009). The influence of fear in decisions: Experimental evidence. Journal of Risk and Uncertainty, 39(3), 271-298. http://dx.doi.org/10.1007/s11166-009-9079-8

Connelly, S., Helton-Fauth, W., \& Mumford, M. D. (2004). A managerial in-basket study of the impact of trait emotions on ethical choice. Journal of Business Ethics, 51(3), 245-267. http://dx.doi.org/10.1023/B:BUSI.0000032494.51162.d3

Cressey, D. R., \& Moore, C. A. (1983). Managerial values and corporate codes of ethics. California Management Review, 25(4), 53-77. http://dx.doi.org/10.2307/41165032

Dejean, C., Courtin, J., Rozeske, R. R., Bonnet, M. C., Dousset, V., Michelet, T., \& Herry, C. (2015). Neuronal circuits for fear expression and recovery: Recent advances and potential therapeutic strategies. Biological psychiatry, 78(5), 298-306. http://dx.doi.org/10.1016/j.biopsych.2015.03.017

Dunsmoor, J. E., \& Paz, R. (2015). Fear generalization and anxiety: Behavioral and neural mechanisms. Biological Psychiatry, 78(5), 336-343. http://dx.doi.org/10.1016/j.biopsych.2015.04.010

Ekman, P. (1999). Basic Emotions. In Dalgleish, T., \& Power, M. J. (Eds.), Handbook of cognition and emotion. Chichester, UK: Wiley. http://dx.doi.org/10.1002/0470013494.ch3

Ethics Resource Center. (2014). 2013 National Business Ethics Survey of the U.S. workforce. Arlington, VA: Ethics Resource Center. Retrieved from: https://www.ethics.org/eci/research/eci-research/nbes/nbes-reports/nbes-2013 
Etzioni, A. (1988). Normative-affective factors towards a new decision-making model. Journal of Economic Psychology, 9, 125-150. http://dx.doi.org/10.1016/0167-4870(88)90048-7

Fetterman, A. K., \& Robinson, M. D. (2013). Do you use your head or follow your heart? Self-location predicts personality, emotion, decision making, and performance. Journal of Personality and Social Psychology, 105(2), 316-334. http://dx.doi.org/10.1037/a0033374

Fischhoff, B., Gonzalez, R. M., Lerner, J. S., \& Small, D. A. (2005). Evolving judgments of terror risks: Foresight, hindsight, and emotion. Journal of Experimental Psychology: Applied, 11(2), 124-139. http://dx.doi.org/10.1037/1076-898x.11.2.124

Flanagan, J., \& Clarke, K. (2007). Beyond a code of professional ethics: A holistic model of ethical decision making for Accountants. Abacus, 43(4), 488-518. http://dx.doi.org/10.1111/j.1467-6281.2007.00242.x

Gaudine, A., \& Thorne, L. (2001). Emotion and ethical decision-making in organizations. Journal of Business Ethics, 31(2), 175-187. http://dx.doi.org/10.1023/A:1010711413444

Guerrette, R. H. (1988). Corporate ethical consulting: developing management strategies for corporate ethics. Journal of Business Ethics, 7(5), 373-380. http://dx.doi.org/10.1007/BF00382540

Goodchild, L. F. (1986). Toward a foundational normative method in business ethics. Journal of Business Ethics, 5(6), 485-499. http://dx.doi.org/10.1007/BF00380755

Herry, C., \& Johansen, J. P. (2014). Encoding of fear learning and memory in distributed neuronal circuits. Nature neuroscience, 17(12), 1644-1654. http://dx.doi.org/10.1038/nn.3869

Hu, Y., Wang, D., Pang, K., Xu, G., \& Guo, J. (2015). The effect of emotion and time pressure on risk $\begin{array}{llll}\text { decision-making. Journal of Risk } & \text { Research, }\end{array}$ http://dx.doi.org/10.1080/13669877.2014.910688

Izard, C. E. (2007). Basic emotions, natural kinds, emotion schemas, and a new paradigm. Perspectives on Psychological Science, 2(3), 260-280. http://dx.doi.org/10.1111/j.1745-6916.2007.00044.x

Kaptein, M. (2004). Business codes of multinational firms: What do they say? Journal of Business Ethics, 50(1), 13-31. http://dx.doi.org/10.1023/B:BUSI.0000021051.53460.da

Kim, J. J., \& Jung, M. W. (2006). Neural circuits and mechanisms involved in Pavlovian fear conditioning: a critical review. Neuroscience \& Biobehavioral Reviews, 30(2), $188-202$. http://dx.doi.org/10.1016/j.neubiorev.2005.06.005

Kligyte, V., Connelly, S., Thiel, C., \& Devenport, L. (2013). The influence of anger, fear, and emotion regulation on ethical decision making. Human Performance, 26(4), 297-326. http://dx.doi.org/10.1080/08959285.2013.814655

KPMG. (2009). Special Services, Business Codes of ethics of the Global 200: their prevalence, Content and embedding, Netherlands, 2008. Retrieved from:

https://www.kpmg.com/ZA/en/IssuesAndInsights/ArticlesPublications/ Documents/BusinessCodes

Krishnakumar, S., \& Rymph, D. (2011). Discrete emotions, moral intensity, \& emotion appraisals in ethics: An extension of Rest's ethical decision-making model. Journal of Global Business Issues, 5(1), 51-58.

Kugler, T., Connolly, T., \& Ordóñez, L. D. (2012). Emotion, decision, and risk: Betting on gambles versus betting on people. Journal of Behavioral Decision Making, 25(2), 123-134. http://dx.doi.org/10.1002/bdm.724

Laufer, W. S., \& Robertson, D. C. (1997). Corporate ethics initiatives as social control. Journal of Business Ethics, 16(10), 1029-1047. http://dx.doi.org/10.1023/A:1017965820673

Lebel, R. D. (2016). Overcoming the fear factor: How perceptions of supervisor openness lead employees to speak up when fearing external threat. Organizational Behavior and Human Decision Processes, 135, 10-21. http://dx.doi.org/10.1016/j.obhdp.2016.05.001

LeDoux, J. E., \& Phelps, E. A. (2008). Emotional networks in the brain. In Lewis, M., Haviland-Jones, J. M., \& Barrett, L. F. (Eds.), Handbook of emotions, New York, NY: The Guilford Press.

Lee, C. J., \& Andrade, E. B. (2011). Fear, social projection, and financial decision making. Journal of Marketing Research, 48(SPL), S121-S129. http://dx.doi.org/10.1509/jmkr.48.SPL.S121

Lee, C. J., \& Andrade, E. B. (2015). Fear, excitement, and financial risk-taking. Cognition and Emotion, 29(1), 178-187. http://dx.doi.org/10.1080/02699931.2014.898611 
Lee, J. J., \& Gino, F. (2015). Poker-faced morality: Concealing emotions leads to utilitarian decision making. Organizational Behavior and Human Decision Processes, 126, 49-64. http://dx.doi.org/10.1016/j.obhdp.2014.10.006

Lerner, J. S., \& Keltner, D. (2001). Fear, anger, and risk. Journal of Personality and Social Psychology, 81(1), 146-159. http://dx.doi.org/10.1037/0022-3514.81.1.146

Lerner, J. S., Li, Y., Valdesolo, P., \& Kassam, K. S. (2015). Emotion and decision making. Annual Review of Psychology, 66, 799-823. http://dx.doi.org/10.1146/annurev-psych-010213-115043

Loewenstein, G., \& Lerner, J. S. (2003). The role of affect in decision making. In Davidson, R. J., Schere, K. R., \& Goldsmith, H. H. (Eds.). Handbook of affective science, New York, NY: Oxford University Press.

Lurie, Y. (2004). Humanizing business through emotions: On the role of emotions in ethics. Journal of Business Ethics, 49(1), 1-11. http://dx.doi.org/10.1023/B:BUSI.0000013851.16825.51

Maner, J. K., \& Gerend, M. A. (2007). Motivationally selective risk judgments: Do fear and curiosity boost the boons or the banes? Organizational Behavior and Human Decision Processes, 103(2), 256-267. http://dx.doi.org/10.1016/j.obhdp.2006.08.002

Ortony, A., \& Turner, T. J. (1990). What's basic about basic emotions? Psychological Review, 97(3), 315-331. http://dx.doi.org/10.1037/0033-295X.97.3.315

Panno, A., Lauriola, M., \& Figner, B. (2013). Emotion regulation and risk taking: Predicting risky choice in deliberative decision making. Cognition \& Emotion, 27(2), 326-334. http://dx.doi.org/10.1080/02699931.2012.707642

Reynolds, S. J. (2006). Moral awareness and ethical predispositions: investigating the role of individual differences in the recognition of moral issues. Journal of Applied Psychology, 91(1), 233-243. http://dx.doi.org/10.1037/0021-9010.91.1.233

Schwartz, M. (2001). The nature of the relationship between corporate codes of ethics and behaviour. Journal of Business Ethics, 32(3), 247-262. http://dx.doi.org/10.1023/A:1010787607771

Shaw, H. (2005). Business ethics. Belmont, CA: Thomson Wadsworth.

Singh, J., Svensson, G., Wood, G., \& Callaghan, M. (2011). A longitudinal and cross-cultural study of the contents of codes of ethics of Australian, Canadian and Swedish corporations. Business Ethics: A European Review, 20(1), 103-119. http://dx.doi.org/10.1111/j.1467-8608.2010.01612.x

Solomon, R. C. (2008). The philosophy of emotions. In Lewis, M., Haviland-Jones, J. M., \& Barrett, L. F. (Eds.), Handbook of emotions, New York, NY: The Guilford Press.

Tiedens, L. Z., \& Linton, S. (2001). Judgment under emotional certainty and uncertainty: the effects of specific emotions on information processing. Journal of Personality and Social Psychology, 81(6), 973-988. http://dx.doi.org/10.1037/0022-3514.81.6.973

Trevino, L. K., Weaver, G. R., Gibson, D. G., \& Toffler, B. L. (1999). Managing ethics and legal compliance: What works and what hurts. California Management Review, 41(2), 131-151. http://dx.doi.org/10.2307/41165990

Tsvetkov, E. A., Krasnoshchekova, E. I., Vesselkin, N. P., \& Kharazova, A. D. (2015). Amygdala: Neuroanatomy and neurophysiology of fear. Journal of Evolutionary Biochemistry and Physiology, 51(6), 456-470. http://dx.doi.org/10.1134/S0022093015060022

Van Zolingen, S. J., \& Honders, H. (2010). Metaphors and the application of a corporate Code of Ethics. Journal of Business Ethics, 92(3), 385-400. http://dx.doi.org/10.1007/s10551-009-0163-4

Velasquez, M. G. (2006). Business ethics, concept and cases. Upper Saddle River, NJ: Pearson Prentice Hall.

Webley, S., \& Werner, A. (2008). Corporate codes of ethics: Necessary but not sufficient. Business Ethics: A European Review, 17(4), 405-415. http://dx.doi.org/10.1111/j.1467-8608.2008.00543.x

Weiss, J. W. (2006). Business ethics: a stakeholder and issues management approach. Mason, OH: Thomson South-Western.

Wenstøp, F. (2005). Mindsets, rationality and emotion in multi-criteria decision analysis. Journal of Multi-Criteria Decision Analysis, 13(4), 161-172. http://dx.doi.org/10.1002/mcda.384

Yip, J. A., \& Côté, S. (2012). The emotionally intelligent decision maker emotion-understanding ability reduces 
the effect of incidental anxiety on risk taking. Psychological Science, 20(10), 1-8.

Zhu, Y. (2015). The Role of Qing (positive emotions) \& $L i$ (rationality) in Chinese entrepreneurial decision making: A Confucian Ren-Yi Wisdom Perspective. Journal of Business Ethics, 126(4), 613-630. http://dx.doi.org/10.1007/s10551-013-1970-1

\section{Copyrights}

Copyright for this article is retained by the author(s), with first publication rights granted to the journal.

This is an open-access article distributed under the terms and conditions of the Creative Commons Attribution license (http://creativecommons.org/licenses/by/4.0/). 